\title{
Cadmium Induced Apoptosis in MG63 Cells by Increasing ROS, Activation of p38 MAPK and Inhibition of ERK 1/2 Pathways
}

\author{
Kong-He Hu ${ }^{a}$ Wen-Xue Lib Min-Ying Sun ${ }^{b}$ She-Bing Zhang ${ }^{a}$ Cai-Xia Fan ${ }^{a}$ \\ Qiang $W^{a}{ }^{a}$ Wei Zhu ${ }^{b}$ Xin $X^{a}$
}

aThe Affiliated Yuebei People's Hospital of Shantou University Medical College, Shaoguan,

${ }^{b}$ Guangzhou Center for Disease Control and Prevention, Guangzhou, China

\author{
Key Words \\ Cadmium • p38MAPK • ERK1/2 • Reactive oxygen species (ROS) • Apoptosis • MG63 cell
}

\begin{abstract}
Background/Aims: Cadmium (Cd) induces apoptosis in different kinds of cells, including osteoblasts, both in vivo and in vitro. However, little is known about the mechanisms by which $\mathrm{Cd}$ induces apoptosis. Methods: In the present study, we used the human osteosarcoma cell line MG63, which has characteristics similar to human osteoblasts, as an in vitro model to determine the cellular mechanisms by which $\mathrm{Cd}$ induces apoptosis. Results: We found that short-term exposure to $\mathrm{CdCl} 2$ induced apoptosis in $\mathrm{MG} 63$ cells. Furthermore, the incubation of cells with $\mathrm{CdCl} 2$ significantly increased the level of phosphorylated p38MAPK and significantly decreased the phosphorylation of ERK1/2 in a concentration-dependent manner. Additionally, the inhibition of the phosphorylation of p38 MAPK by SB202190 protected MG63 cells from Cd-induced apoptosis. The incubation of MG63 cells with the ERK1/2 inhibitor PD98059 significantly increased apoptosis in MG63 cells. $\mathrm{CdCl} 2$ also significantly increased the intracellular levels of ROS. N-acetylcysteine (NAC) significantly reduced ROS levels and reversed the effects of $\mathrm{CdCl} 2$ on MAPK signaling. Conclusion: Our results suggested that $\mathrm{Cd}$ induced apoptosis in MG63 cells by increasing ROS, activation of p38 MAPK and inhibition of ERK1/2 pathways.
\end{abstract}

Xin Xu

KARGER 125
Department of orthopaedics, The Affiliated Yuebei People's Hospital of Shantou University Medical College, No.133, Huimin S road, Shaoguan, 512025Guangdong Province, (China); E-Mail shaoguanxx@126.com 


\section{Cellular Physiology Cell Physiol Biochem 2015;36:642-654 \\ \begin{tabular}{ll|l} 
and Biochemistry & $\begin{array}{l}\text { DOI: 10.1159/000430127 } \\
\text { Published online: May } 182015\end{array}$ & $\begin{array}{l}\text { ○ 2015 S. Karger AG, Basel } \\
\text { www.karger.com/cpb }\end{array}$ \\
\hline
\end{tabular} \\ Hu et al.: Cadmium Induced Apoptosis in MG63 Cells}

\section{Introduction}

Bone tissue is consistently remodeled by osteoclasts and osteoblasts. Osteoclasts participate in the degradation of old bone, whereas osteoblasts play an important role in bone formation and mineralization. Osteoblasts, in addition to their role in bone maintenance, also secrete factors involved in osteoclastic differentiation[1]. The viability of osteoblasts is critical in maintaining the development and integrity of bone tissue. Bone loss due to osteoporosis may be caused partly by osteoblast dysfunction as a result of cell cycle inhibition or cell death[2]. Numerous studies have reported that bone loss caused by gonadal steroid deficiency, glucocorticoid excess, or aging is partially attributed to the apoptosis of osteoblasts. The drugs bisphosphonate and calcitonin could produce anabolic effects on bone by suppressing the apoptosis of osteoblasts [3-7]. Therefore, compounds that act by either increasing cell apoptosis or death of osteoblasts could produce bone diseases including osteoporosis.

Cadmium (Cd), a toxic transition metal, has been widely used in industry for many years and contaminates agricultural soil in many parts of the world. The prolonged or excessive exposure to $\mathrm{Cd}$ has been reported to have harmful health effects in humans, including bone disease. In Japan, the excessive intake of Cd produces itai-itai disease, characterized by severe renal dysfunction with parallel osteomalacic and osteoporotic lesions[8]. Recently, a series of cross-sectional and prospective studies have demonstrated a correlation between $\mathrm{Cd}$ exposure and low bone mineral density, as well as an increased risk of osteoporosis[9]. The exposure to Cd may be associated with a higher risk of osteoporosis in human [10-12] and experimental animals [13-18]. However, the mechanisms responsible for these adverse effects remain to be elucidated. In vitro studies suggest that Cd may directly alter osteoblast function, viability and induce osteoblast apoptosis, thereby disrupting the balance of bone formation and degradation [19-22]. However, the cellular mechanisms responsible for Cdinduced apoptosis of osteoblasts remain to be determined.

The mammalian mitogen-activated protein kinases (MAPKs) are a family of serine/ threonine kinases. There are three major components that include the extracellular signalregulated kinase (ERK), C-JUN N-terminal kinase (JNK) and p38 kinase. MAPKs have been reported to be involve in various cellular functions such as cell growth, differentiation and apoptosis[23]. MAPKs are activated by upstream protein kinases, which regulate gene expression through phosphorylation of downstream transcriptional factors [24, 25]. MAPKs pathways have been proved to play important roles in the regulation of apoptosis induced by different cellular toxicity[24,25]. Many environmental and genotoxic stimuli, such as UV irradiation, heavy mental, or heat shock, could induce the activation of p38 MAPK, which was considered as stress kinases. Activated p38 MAPK signaling has been shown to promote cell apoptosis $[26,27]$. However, it has been shown that under certain conditions, p38 MAPK can also mediate resistance to apoptosis[28, 29]. Therefore the role of p38 MAPK in apoptosis depends on the cell types and stimuli[30]. Many researches have elucidated that ERK1/2 signaling was associated with cell survival and proliferation. Various growth factors could activate ERK1/2 and promote cell transition from quiescent state into cell cycle [30]. Inhibition of ERK1/2 by specific inhibitor could generally induce cell apoptosis [31-33]. As the same with p38 MAPK, some reports also found that ERK1/2 have a dual role in the process of apoptosis[24]. Cd, in vitro, has been reported to induce apoptotic cell death as well as necrosis through MAPKs pathways [23, 34-38]. However, the role of MAPKs signaling in osteoblastic cellular apoptosis following exposure to $\mathrm{Cd}$ has not been clearly delineated.

Reactive oxygen species (ROS) are generally produced in the mitochondria or from other sources. When the antioxidative defense becomes weaker, or ROS is over generated, seriously damage to proteins, lipids and DNA are induced. These cell damage could ultimately lead to cell death or apoptosis[39]. MAPKs family has been proved to be commonly involved in the apoptosis induced by ROS generation[40]. Cd exposure significantly increases ROS generation through the depletion of glutathione and protein-bound sulfhydryl groups in cells [41-44]. In human osteoblastic cells, it is unknown as to how Cd induces apoptosis. 


\section{Cellular Physiology Cell Physiol Biochem 2015;36:642-654 \begin{tabular}{ll|l} 
and Biochemistry & $\begin{array}{l}\text { DOI: 10.1159/000430127 } \\
\text { Published online: May } 182015\end{array}$ & $\begin{array}{l}\text { ○ 2015 S. Karger AG, Basel } \\
\text { www.karger.com/cpb }\end{array}$ \\
\hline
\end{tabular}}

Hu et al.: Cadmium Induced Apoptosis in MG63 Cells

The human osteosarcoma cell line, MG63, possesses characteristics similar to human osteoblasts and has been used as a model for research related to human osteoblasts [45]. Therefore, in this study, we used MG63 cells as an in vitro model to investigate the effect of $\mathrm{Cd}$ (using $\mathrm{CdCl}_{2}$ ) on cell proliferation and apoptosis. We also conducted experiments to determine if p38MAPK, ERK1/2 and ROS were involved in inducing apoptosis

\section{Materials and Methods}

\section{Reagents}

Cadmium chloride $\left(\mathrm{CdCl}_{2}\right.$ ), N-acetyl cysteine (NAC), and 2,7-dichlorofluorescin diacetate (DCFDA) were obtained from Sigma-Aldrich (St Louis, MO). Dulbecco's Modified Eagle Medium (DMEM), with high glucose, penicillin, streptomycin and fetal bovine serum (FBS) were obtained from Life technologies. Antibodies against Phospho-p44/42 MAPK (Erk1/2) (Thr202/Tyr204), Phospho-p38 MAPK (Thr180/Tyr182) and $\beta$-actin were purchased from Cell Signaling Technology (CST) (Beverly, MA). PD98059 and SB202190 were obtained from Selleck Chemicals (Houston, Tx, USA). The CCK-8 Cell Proliferation and Cytotoxicity Assay Kit was purchased from Beyotime Institute of Biotechnology (Shanghai, China).

\section{Cell Culture}

MG63 cells were obtained from the Chinese Academy of Sciences (Shanghai, China). MG63 cells were maintained in DMEM, supplemented with 10\% FBS, $100 \mathrm{U} / \mathrm{mL}$ penicillin G and $100 \mu \mathrm{g} / \mathrm{mL}$ streptomycin and incubated at $37^{\circ} \mathrm{C}$ in a water-saturated atmosphere with $5 \% \mathrm{CO}_{2}$.

MG63 cells were seeded in 6-well plates at a density of $5 \times 10^{5}$ cells/well. After incubation overnight, cells were incubated with $\mathrm{CdCl}_{2}(10,20,30,40,50$ and $60 \mu \mathrm{M})$ for 24 hours or 48 hours. In experiments to determine the effects of p38MAPK on Cd-induced phospho-p38 MAPK, cells were incubated with the p38 inhibitor SB202190 (10, 20 and $30 \mu \mathrm{M})$ for 1 hour and then co-incubated with $\mathrm{CdCl}_{2}(50 \mu \mathrm{M})$ for 24 hours. In addition, cells were incubated with the ERK1/2 inhibitor PD98059 (30, 40 and $50 \mu \mathrm{M})$ for 24 hours. Subsequently, the cells were collected for apoptosis measurement.

\section{Cell viability assay}

Cell proliferation was determined using the CCK-8 assay as previously described [38]. Briefly, MG63 were seeded at a density of $5 \times 10^{3}$ cells/well in 96-well plates. After attachment for 24 hours, the medium was changed for fresh medium containing 10, 20,30, 40, 50 and $60 \mu \mathrm{M} \mathrm{CdCl}_{2}$ and cells were incubated for 24 or 48 hours. Subsequently, $10 \mu \mathrm{L}$ CCK-8 solution was added to each well, and cells were incubated for 2 hours at $37^{\circ} \mathrm{C}$. Cell viability was determined by recording the $\mathrm{OD}$ at a test wavelength $450 \mathrm{~nm}$ and a reference wavelength $630 \mathrm{~nm}$ using a microplate reader.

\section{Apoptosis assay}

Cell apoptosis was detected using flow cytometric analysis as previously described [46]. In brief, cells were incubated with the indicated concentrations of $\mathrm{CdCl}_{2}$. Then cells were harvested, washed twice with washing buffer, and resuspended in binding buffer at $1 \times 10^{5}$ cells $/ \mathrm{ml}$. A $100 \mu$ laliquot of the suspension was incubated with $5 \mu \mathrm{l}$ of Annexin V-PE and $5 \mu \mathrm{l}$ of propidium iodide $(20 \mu \mathrm{g} / \mathrm{mL})$ in the dark for $20 \mathrm{~min}$ at room temperature. Finally, $400 \mu \mathrm{l}$ of binding buffer was added to each sample, and samples were analyzed using flow cytometry within one hour.

\section{Quantification of intracellular reactive oxygen species}

The intracellular ROS levels were measured using the 2,7-dichlorofluorescin diacetate (DCFDA) method. DCFDA diffuses rapidly into the cells and yield DCFH. Intracellular ROS $\left(\mathrm{H}_{2} \mathrm{O}_{2}\right.$ and $\left.\mathrm{OH}\right)$ interact with DCFH and convert it to the fluorescent compound DCF. MG63 cells were cultured in a 6-well plate. When $70 \%-80 \%$ confluence was reached, the cells were exposed to different concentrations of $\mathrm{CdCl}_{2}$ for 24 hours. Subsequently, the cells were incubated with $10 \mu \mathrm{l}$ DCFDA in $1 \mathrm{ml}$ PBS for 30min at room temperature, and the resulting DCF fluorescence was detected using a flow cytometer. 


\section{Cellular Physiology Cell Physiol Biochem 2015;36:642-654 \begin{tabular}{ll|l} 
DOI: 10.1159/000430127 & O 2015 S. Karger AG, Bas
\end{tabular}}

Hu et al.: Cadmium Induced Apoptosis in MG63 Cells

Fig. 1. $\mathrm{CdCl}_{2}$ inhibits proliferation of MG63 cells. MG63 cells were exposed to $0,10,20,30$, 40,50 and $60 \mu \mathrm{M} \mathrm{CdCl}_{2}$ for 24 or 48 hours. (A) Cell morphology under light microscopy (X100). No significant morphological changes were seen. (B) Cell viability determined by the CCK-8 assay. Each point represents the mean \pm SD of three independent experiments. The statistical significance was determined by one-way ANOVA $\left({ }^{*} \mathrm{P}<0.05\right.$, ${ }^{* *} \mathrm{P}<0.01$ versus buffer control).

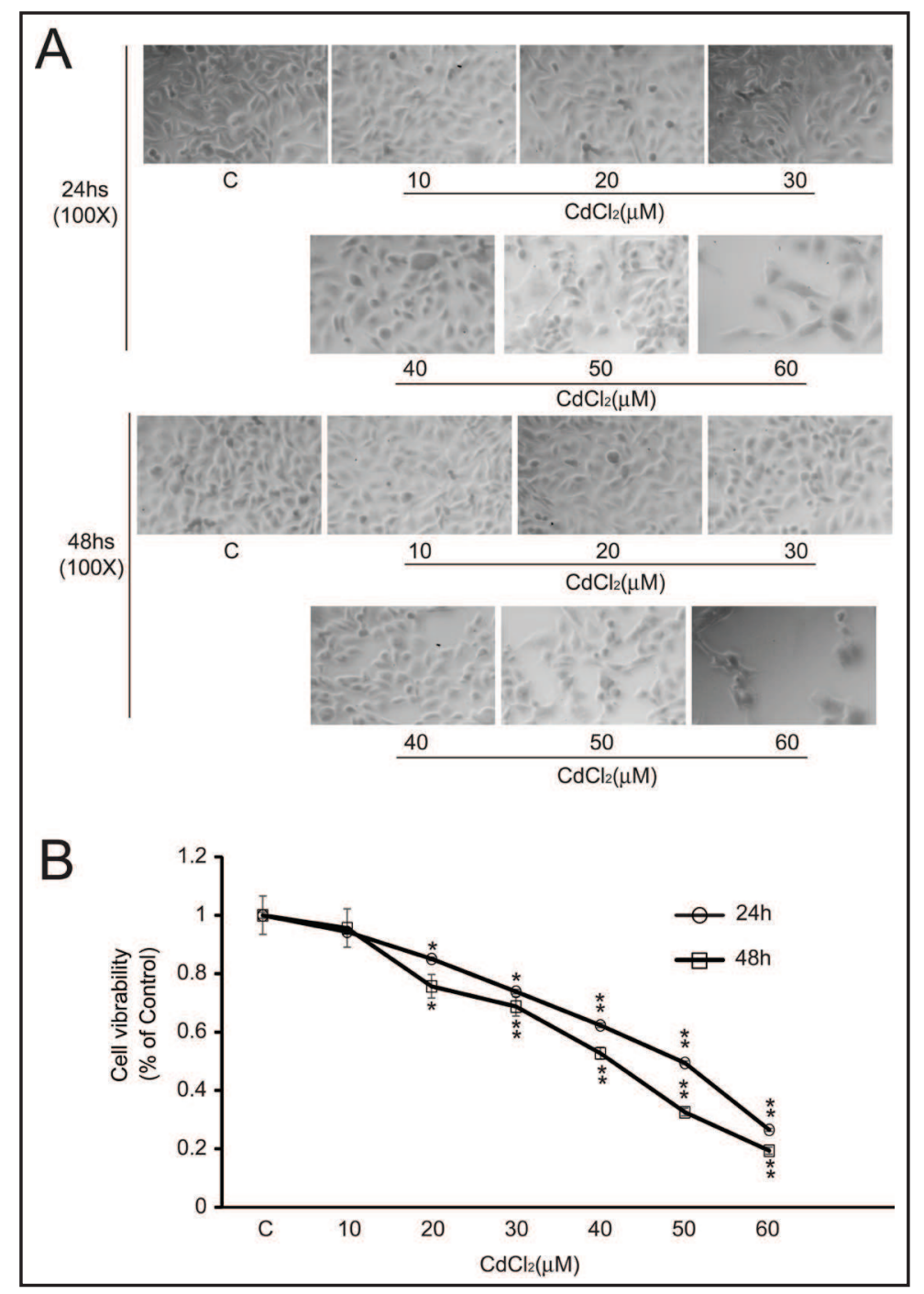

Western blot analysis

Western blot analysis was performed as previously described [46]. Cells were pelleted by centrifugation at $320 \times \mathrm{g}$ for $10 \mathrm{~min}$ and resuspended in lysis buffer $(20 \mathrm{mM}$ Tris- $\mathrm{HCl} \mathrm{pH} \mathrm{7.4,2} \mathrm{mM} \mathrm{EDTA,} 500 \mu \mathrm{M}$ sodium orthovanadate, $1 \%$ Triton X-100, 0.1\% SDS, $10 \mathrm{mM} \mathrm{NaF}, 10 \mu \mathrm{g} / \mathrm{mL}$ leupeptin, and $1 \mathrm{mM}$ PMSF). Aliquots (20 $\mu \mathrm{g}$ ) of the lysates were separated on a 10\% SDS-polyacrylamide gel and transferred to a PVDF membrane. Blots were blocked for 2 hours in 5\% non-fat dry milk in PBST buffer and incubated with primary antibodies overnight at $4^{\circ} \mathrm{C}$. After washing with PBST (10 mM phosphate buffer, $2.7 \mathrm{mM} \mathrm{KCl,} 140 \mathrm{mM} \mathrm{NaCl}$ and $0.05 \%$ Tween 20, pH 7.4), the appropriate HRP-conjugated secondary antibody was added to the preparation. Then the blot was incubated at $37^{\circ} \mathrm{C}$ for 1 hour and developed using an enhanced chemiluminescence detection system (Beyotime Institute of Biotechnology, China).

Statistical analysis

SPSS for Windows version 13.0 was used for statistical analysis. The data were presented as the mean \pm standard deviation. The quantitative values were analyzed through Student's t test after analyzing via ANOVA. The level of statistical significance was set at $\mathrm{P}<0.05$.

\section{Results}

$\mathrm{CdCl}_{2}$ significantly inhibited the proliferation of MG63 cells

As shown in Figure 1A incubation 10 or $20 \mu \mathrm{M} \mathrm{CdCl}_{2}$ for 24 hours or 48 hours did not induce significant changes in cell morphologic features, but cell confluence was significantly 
A
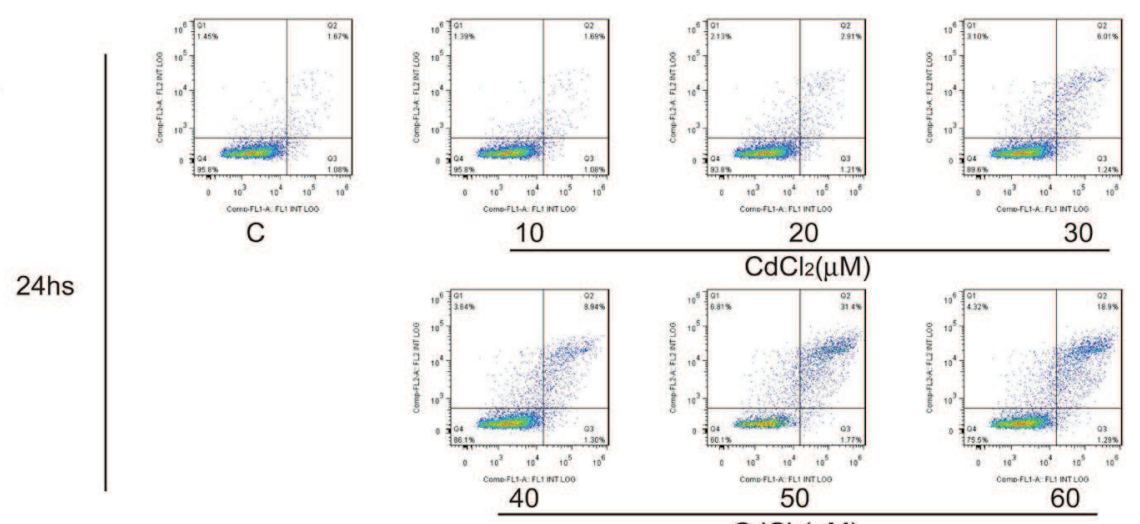

$\mathrm{dCl}_{2}(\mu \mathrm{M})$
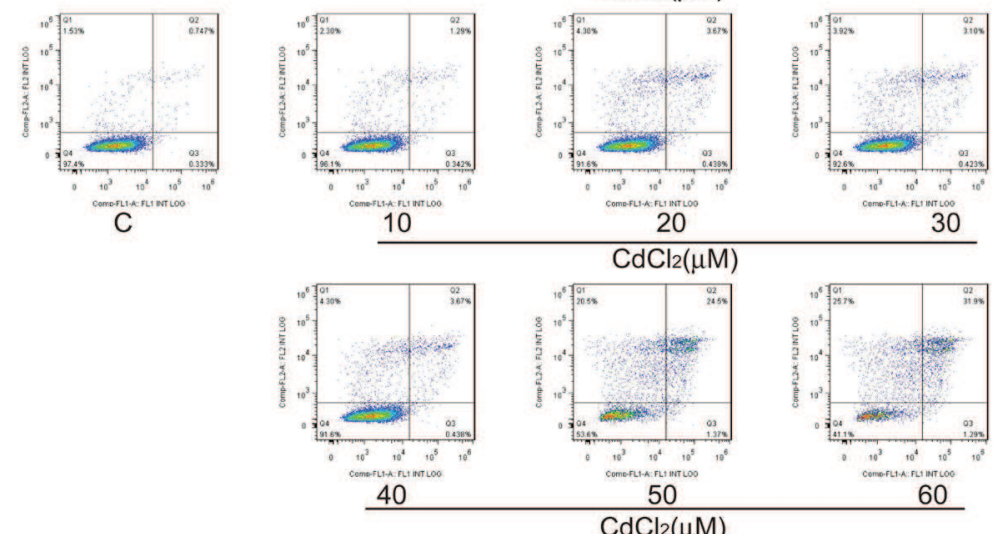

50

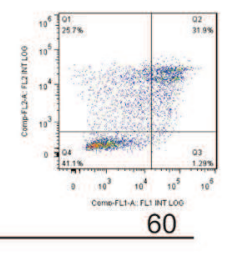

B
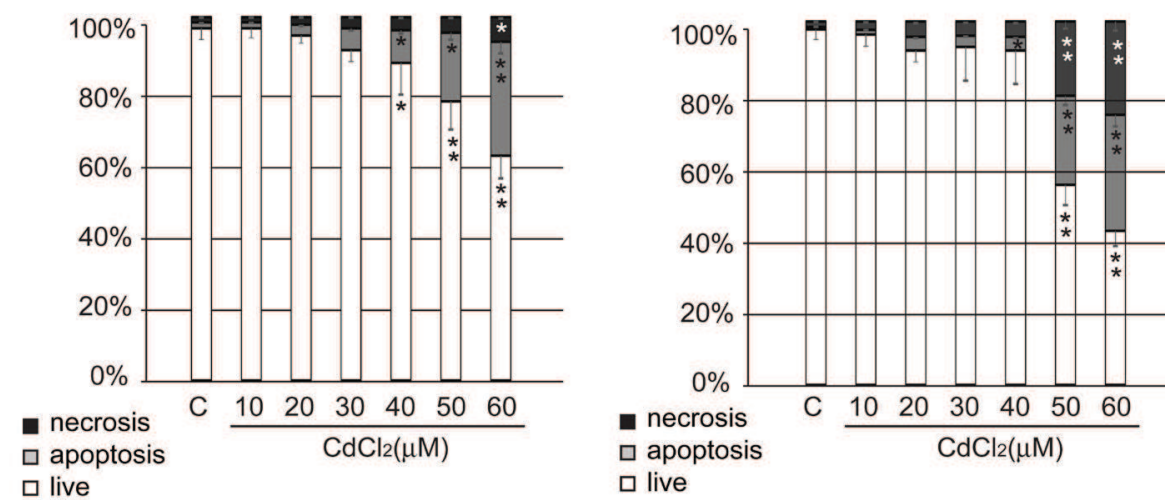

$24 \mathrm{hs}$

$48 \mathrm{hs}$

Fig. 2. $\mathrm{CdCl}_{2}$ induces cell apoptosis. MG63 cells incubated with $0,10,20,30,40,50$ and $60 \mu \mathrm{M} \mathrm{CdCl}_{2}$ for 24 or 48 hours. The apoptotic rate was analyzed by flow cytometry. The results are from one representative experiment of three performed that showed similar patterns. Each point represents the mean \pm SD of three independent experiments. The statistical significance was determined by one-way ANOVA $\left({ }^{*} \mathrm{P}<0.05\right.$, $* * \mathrm{P}<0.01$ versus untreated control).

decreased. Incubation with $40 \mu \mathrm{M} \mathrm{CdCl}_{2}$ produced morphological changes indicative of cell death. The results of the CCK-8 assay were consistent with morphologic features. As shown in Figures $1 \mathrm{~B}$, incubation with up to $20 \mu \mathrm{M} \mathrm{CdCl}_{2}$ for 24 hours or 48 hours resulted in a concentration -dependent inhibition of cell proliferation. The incubation of cells with $50 \mu \mathrm{M}$ $\mathrm{CdCl}_{2}$ for 24 hours or $40 \mu \mathrm{M}$ for 48 hours significantly reduced cell proliferation. 


\section{Cellular Physiology Cell Physiol Biochem 2015;36:642-654 \begin{tabular}{l|l} 
DOI: 10.1159/000430127 & O 2015 S. Karger AG, Basel
\end{tabular} and Biochemistry Published online: May 182015 www.karger.com/cpb}

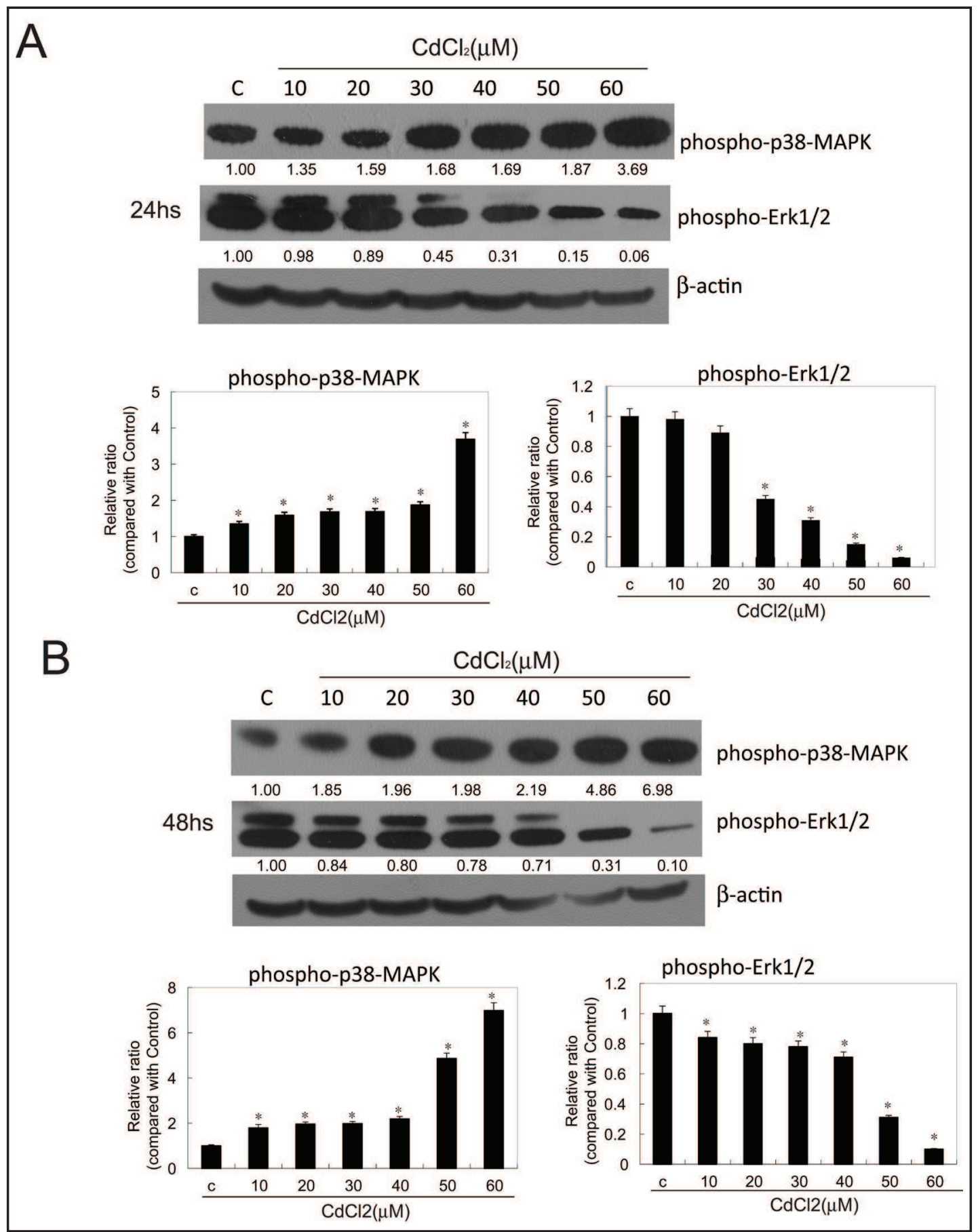

Fig. 3. $\mathrm{CdCl}_{2}$ increases p38 MAPK phosphorylation and decreases ERK1/2 phosphorylation. MG63 cells incubated with $0,10,20,30,40,50$ and $60 \mu \mathrm{M} \mathrm{CdCl}_{2}$ for 24 or 48 hours. Western blotting was used to determine the levels of phospho-p44/42 MAPK (Erk1/2) (Thr202/Tyr204) and phospho-p38 MAPK (Thr180/ Tyr182). The results were representative of at last three independent experiments. $\beta$-actin was used as an internal reference. The intensity of bands was quantified by densitometric analysis.

$\mathrm{CdCl}_{2}$ induces apoptosis in MG63 cells

The results of cell flow cytometry were shown in Figures 2. Cells treated with $\mathrm{CdCl}_{2}$ at concentrations of 50 and $60 \mu \mathrm{M}$ for 24(Fig. 2A) and 48 hours (Fig. 2B), show significant apoptosis. Apoptosis occurred in a time- and concentration -dependent manner compared 


\section{Cellular Physiology Cell Physiol Biochem 2015;36:642-654 \begin{tabular}{l|l|l} 
DOI: 10.1159/000430127 & O 2015 S. Karger AG, Basel
\end{tabular} and Biochemistry Published online: May 182015 www.karger.com/cpb}

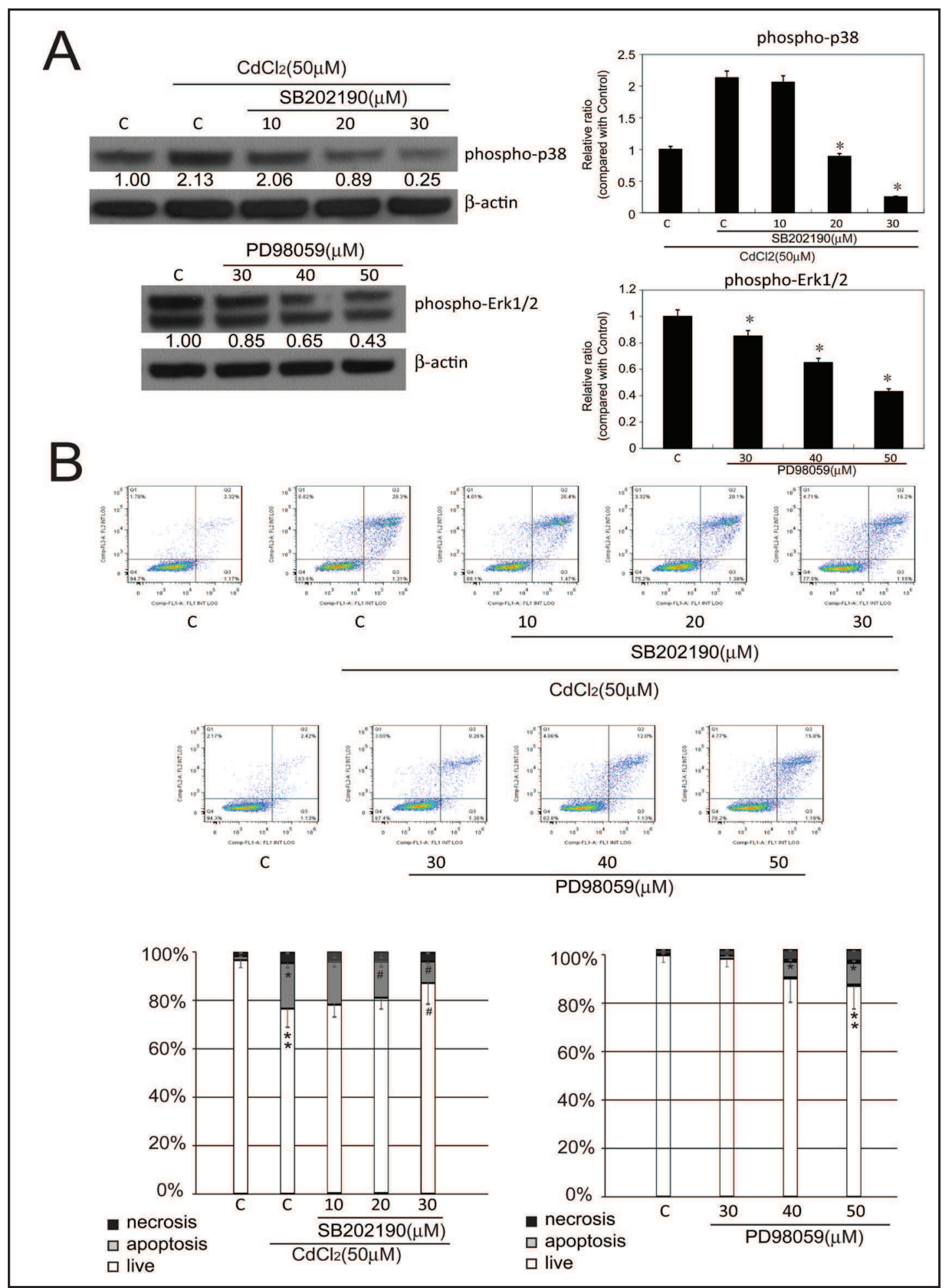

Fig. 4. The effect of a p38MAPK and ERK inhibitor on $\mathrm{CdCl}_{2}$-induced apoptosis. (A) Western blotting to determine the levels of phospho- Erk1/2 and phospho-p38 MAPK. The results were representative of at least three independent experiments. Beta-actin was used as an internal reference. The intensity of bands was quantified by densitometric analysis. (B)The apoptotic rate by flow cytometry. The results are from one representative experiment of three performed that showed similar patterns. Each point represents the mean $\pm \mathrm{SD}$ of three independent experiments. The statistical significance was determined by one-way ANOVA $\left({ }^{*} \mathrm{P}<0.05,{ }^{*} \mathrm{P}<0.01\right.$ versus control; $\# \mathrm{P}<0.05$, \#\#P<0.01 versus cells treated with $50 \mu \mathrm{M} \mathrm{CdCl}_{2}$ alone). 

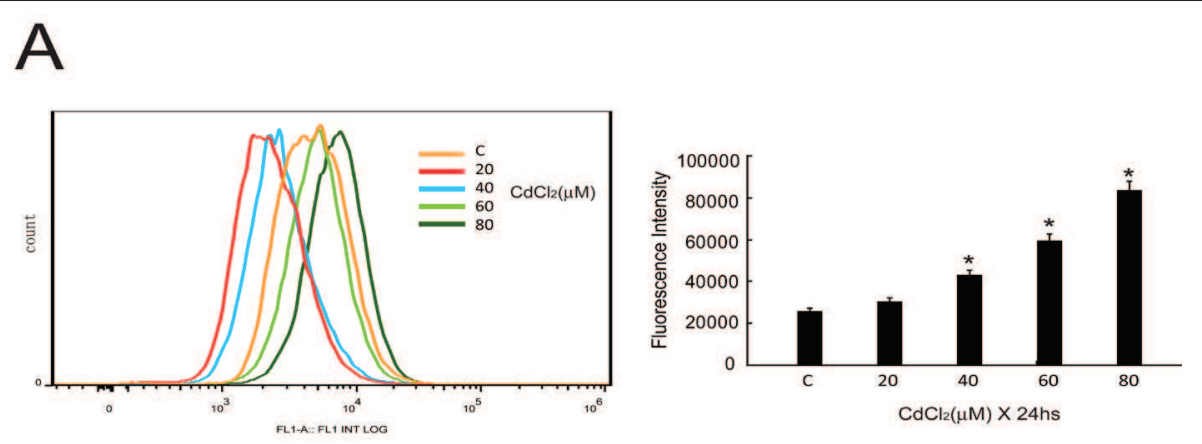

B
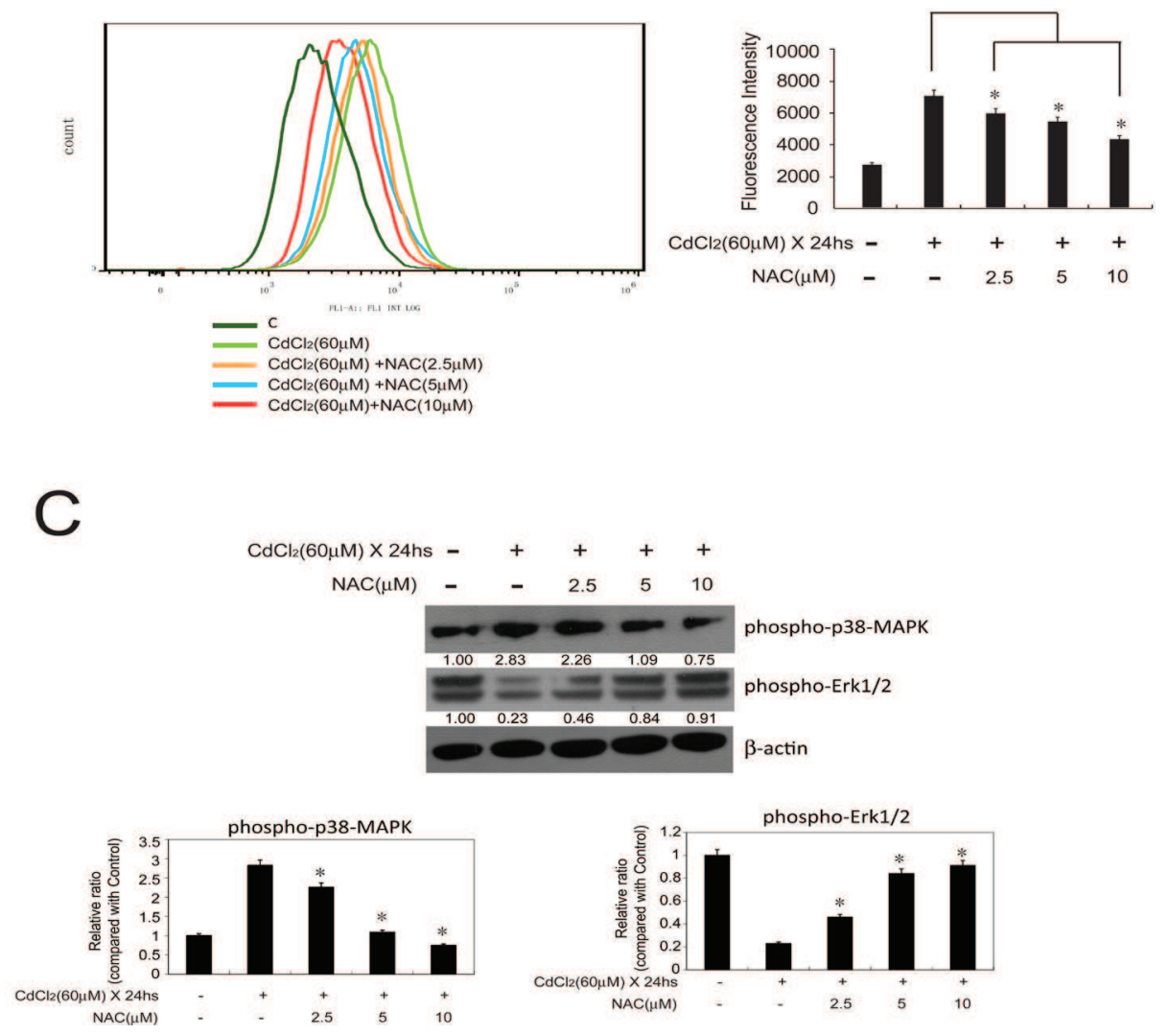

Fig. 5. $\mathrm{CdCl}_{2}$ alters MAPKs signaling by increasing ROS levels. (A) MG63 cells were incubated with (0, 20, 40, 60 and $80 \mu \mathrm{M}) \mathrm{CdCl}_{2}$ for 24 hours and subsequently ROS levels were analyzed by flow cytometry. Each point represents the mean \pm SD of three independent experiments. The statistical significance was determined by one-way ANOVA $\left({ }^{*} \mathrm{P}<0.05,{ }^{*} \mathrm{P}<0.01\right.$ versus control). (B)MG63 cells were incubated with medium containing $\mathrm{NAC}(0,2.5,5$ and $10 \mu \mathrm{M})$ and $60 \mu \mathrm{M} \mathrm{CdCl}_{2}$ for 24 hours. ROS levels were analyzed by flow cytometry. Each point represents the mean $\pm \mathrm{SD}$ of three independent experiments. The statistical significance was determined by one-way ANOVA $\left({ }^{*} \mathrm{P}<0.05,{ }^{* *} \mathrm{P}<0.01\right.$ versus cells treated with $50 \mu \mathrm{M} \mathrm{CdCl}_{2}$ alone). (C) Western blotting to determine the levels of phospho-p44/42 MAPK (Erk1/2) (Thr202/Tyr204) and phospho-p38 MAPK (Thr180/Tyr182). The results were representative of at least three independent experiments. Beta-actin was used as an internal reference. The intensity of the gel bands was quantified by densitometric analysis.

with control MG63 cells. (50 $\mu \mathrm{M}, 24$ hours, $18.9 \pm 0.2 \%$; $\mathrm{p}<0.05$; $50 \mu \mathrm{M}, 48$ hours, $24.5 \pm 0.3 \%$, $\mathrm{p}<0.01$ ).

\section{KARGER}




\section{Cellular Physiology Cell Physiol Biochem 2015;36:642-654 \\ \begin{tabular}{ll|l} 
DOI: 10.1159/000430127 & $\begin{array}{l}\text { C 2015 S. Karger AG, Basel } \\
\text { www.karger.com/cpb }\end{array}$ \\
\hline
\end{tabular}}

The incubation of cells with $\mathrm{CdCl}_{2}$ significantly increased the phosphorylation of p38MAPK and reduced ERK1/2 phosphorylation levels

In order to evaluate the changes in MAPKs pathway after $\mathrm{CdCl}_{2}$ exposure, MG63 cells were treated with indicated concentration of $\mathrm{CdCl}_{2}$ for 24 hours or 48 hours and the activation of p38 and ERK1/2 was then determined using specific phospho-antibodies. As shown in Figure 3, the incubation of cell with $\mathrm{CdCl}_{2}$ for 24 or 48 hours significantly increased the level of the phosphorylated form of p38 in a concentration-dependent manner. In contrast, $\mathrm{CdCl}_{2}$ (10-60 $\mu \mathrm{M})$ significantly decreased the levels of phosphorylated ERK1/2 in a concentration -dependent manner.

The effects of MAPK inhibitors on $\mathrm{CdCl}_{2}$-induced apoptosis

As shown in Figure 4A, SB202190 $(10,20$ or $30 \mu \mathrm{M})$ significantly decreased the level of phosphorylated p38 induced by $\mathrm{CdCl}_{2}(50 \mu \mathrm{M})$ in a concentration -dependent manner. The effect of SB202190 on CdCl2-induced apoptosis was evaluated by flow cytometric analysis, as shown in Figure 4B. SB202190 significantly decreased the apoptosis rate of MG63 induced by $\mathrm{CdCl}_{2}$ by $20.1 \% \pm 5.4 \%(20 \mu \mathrm{M})$ and $16.2 \% \pm 3.2 \%(30 \mu \mathrm{M})$ compared to cells incubated with $\mathrm{CdCl}_{2}$ alone. PD98059, a specific inhibitor of the enzyme that phosphorylates ERK1/2, significantly decreased the level of the phosphorylated form of ERK1/2 in MG63 cells, as shown in Figure 4A, in a concentration -dependent manner (30, 40 and $50 \mu \mathrm{M})$. We also found that PD98059 alone could induce the apoptosis of MG63 cells (Fig. 4B). PD98059 significantly increased the percentage of apoptotic cells to $8.26 \% \pm 1.4 \%(30 \mu \mathrm{M}), 12.0 \% \pm 3.2 \%(40 \mu \mathrm{M})$ and $15.8 \% \pm 2.5 \%(50 \mu \mathrm{M})$ compared with control cells after a 24-hour incubation period.

ROS induced by $\mathrm{CdCl}_{2}$ participated in the effects of $\mathrm{CdCl}_{2}$ on MAPKs pathways.

The rapid generation of ROS by $\mathrm{CdCl}_{2}$ exposure has been reported to induce apoptosis in other cells [44]. In order to determine if ROS plays a role in $\mathrm{CdCl}_{2}$-induced apoptosis, we measured ROS generation in $\mathrm{CdCl}_{2}$ treated MG63 cells. The incubation of cells with 40, 50 or $60 \mu \mathrm{M}$ of $\mathrm{CdCl}_{2}$ for 24 hours significantly increased ROS levels (Fig. 5A). The incubation of MG63 cells with the ROS scavenger NAC $(2.5-10 \mu \mathrm{M})$, as shown in Fig5B, significantly decreased the levels of ROS generated by $60 \mu \mathrm{M} \mathrm{CdCl}_{2}$. Western blot results indicated that NAC significantly inhibited the Cd-induced phosphorylated form of p38-MAPK and significantly decreased ERK1/2 phosphorylation as shown in Fig5C.

\section{Discussion}

In the current study, we found that MG63 cells treated with $\mathrm{CdCl}_{2}$ for 24 or 48 hours increased the level of phosphorylated form of p38 and decreased the phosphorylation of ERK1/2 in a concentration-dependent manner. The change of the levels of phosphorylated p38 and ERK1/2 happened before the apoptosis induced by Cd. This illustrated that p38 and ERK1/2 might participate in the process of apoptosis induced by $\mathrm{Cd}$. In order to confirm the role of the activation of p38 MAPK induced by Cd, we used the specific inhibitor SB202190 to inhibit the phosphorylation of MAPK. We found that decreasing of phospho-p38 MAPK by SB202190 prevent the apoptosis of MG63 cells induced by $\mathrm{CdCl}_{2}$. This is consistent with previous reports $[47,48]$. Treatment with the inhibitor of ERK1/2 PD98059 also led to apoptosis in MG63 cells. This result is not consistent with data collected from Saos-2 cells $[19,49]$. One possible explanation is the difference of cell lines. The labelling profile tests revealed that MG-63 showed both mature and immature osteobalstic features and Saos-2 cells represented a mature phenotype. The heterogeneous of varying degrees of cell differentiation might lead to different responses to the same kinds of poisons. Taken together, $\mathrm{CdCl}_{2}$ induced apoptosis of osteoblast-like MG63 cells might relate to the activation of p38 MAPK and the inhibition of ERK1/2 pathways.

The generation of ROS induced by Cd exposure play an important role in Cd-induced cell cycle arrest and apoptosis. This has been proved in many kinds of tissues and cells such 


\section{Cellular Physiology Cell Physiol Biochem 2015;36:642-654 \begin{tabular}{l|l} 
and Biochemistry Published online: May 182015 & $\begin{array}{l}\text { O 2015 S. Karger AG, Base } \\
\text { www.karger.com/cpb }\end{array}$ \\
\cline { 1 - 2 }
\end{tabular}

as neuronal cells in brain[50], kidney cells [43, 51], immune cells[41]and liver cells [44]. Furthermore, in osteoblast-like cells Saos-2 and Mc3T3-E1, Cd exposure induced apoptotic cell death via ROS and the antioxidant N-acetylcysteine (NAC) prevented apoptosis [22, 49, 52]. In our study, we detected the ROS generation triggered by $\mathrm{CdCl}_{2}$ and found that the treatment with different concentrations of $\mathrm{CdCl}_{2}$ increased ROS generation in MG63. ROS could regulate MAPKs signaling involved in cell apoptosis in response to various stimuli [53, 54]. p38 MAPK is proved to be mainly activated through ROS and initiate the progress of apoptosis. ERK1/2 has been shown to be inhibited by ROS and the pro-survival effects were blunted [54]. Therefore ROS/MAPKs signaling might be the important mechanism involved in the apoptosis induced by Cd in MG63 cells. In order to understand the roles of ROS in the apoptotic process, we detected the effects of the ROS scavenger NAC on the MAPKs signaling activation via $\mathrm{CdCl}_{2}$. When we treated MG63 cells with NAC and $\mathrm{CdCl}_{2}$ at the same time, results showed that NAC treatment decreased ROS levels, increased phosphorylated form of p38-MAPK and inhibited ERK1/2 phosphorylation. We suggested that the exposure of $\mathrm{CdCl}_{2}$ increases cell apoptosis via ROS/MAPKs signaling in osteoblast-like MG63 cells.

In conclusion, we have documented that cytotoxic doses of $\mathrm{Cd}$ inhibited the proliferation and induced apoptosis in osteoblast-like MG63 cells. Our findings suggested that $\mathrm{CdCl}_{2}$ activated p38 MAPK and inactivated ERK1/2, leading to induction of cell apoptosis. The activation of p38 MAPK and the inhibition of ERK1/2 pathways play an important role in apoptosis induced by Cd in MG63.

\section{Acknowledgements}

This work was supported by grants from The National Natural Science Foundation of China (grant no. 81101562); The Natural Science Foundation of Guangdong Province (grant no. S2012010009633); The Project of Science and Technology of Guangdong Province (grant no.2012B060300005); Key Project Guangzhou Medical and Health Science and Technology (grant no. 20121A021018); and The Project for Key Medicine Discipline Construction of Guangzhou Municipality (grant no. 2013-2015-07).

The authors have no other relevant affiliations or financial involvement with any organization or entity with a financial interest in or financial conflict with the subject matter or materials discussed in the manuscript apart from those disclosed.

No writing assistance was utilized in the production of this manuscript.

\section{Disclosure Statement}

The authors declare no conflict of interest of this work.

\section{References}

1 Mackie EJ: Osteoblasts: novel roles in orchestration of skeletal architecture. Int J Biochem Cell Biol 2003;35:1301-1305.

2 Bonewald LF: Osteocyte biology: its implications for osteoporosis. J Musculoskelet Neuronal Interact 2004;4:101-104.

3 Migliaccio S, Brama M, Fornari R, Greco EA, Spera G, Malavolta N: Glucocorticoid-induced osteoporosis: an osteoblastic disease. Aging Clin Exp Res 2007;19:5-10.

4 Pignolo RJ, Suda RK, McMillan EA, Shen J, Lee SH, Choi Y, Wright AC, Johnson FB: Defects in telomere maintenance molecules impair osteoblast differentiation and promote osteoporosis. Aging Cell 2008;7:2331.

5 Whitfield JF, Morley P, Willick GE: Parathyroid hormone, its fragments and their analogs for the treatment of osteoporosis. Treat Endocrinol 2002;1:175-190. 


\section{Cellular Physiology Cell Physiol Biochem 2015;36:642-654 \begin{tabular}{l|l} 
DOI: 10.1159/000430127 & (c) 2015 S. Karger AG, Basel
\end{tabular} and Biochemistry Published online: May 182015 www.karger.com/cpb}

Hu et al.: Cadmium Induced Apoptosis in MG63 Cells

6 Yudoh K, Matsuno H, Kimura T: [Relationship between periarticular osteoporosis and osteoblast senescence in patients with rheumatoid arthritis]. Clin Calcium 2001;11:612-618.

7 Zikan V: [Glucocorticoids and osteoporosis]. Vnitr Lek 2007;53:831-840.

8 Pier SM: The role of heavy metals in human health. Tex Rep Biol Med 1975;33:85-106.

9 Akesson A, Barregard L, Bergdahl IA, Nordberg GF, Nordberg M, Skerfving S: Non-renal effects and the risk assessment of environmental cadmium exposure. Environ Health Perspect 2014;122:431-438.

10 Staessen JA, Roels HA, Emelianov D, Kuznetsova T, Thijs L, Vangronsveld J, Fagard R: Environmental exposure to cadmium, forearm bone density, and risk of fractures: prospective population study. Public Health and Environmental Exposure to Cadmium (PheeCad) Study Group. Lancet 1999;353:1140-1144.

11 Alfven T, Elinder CG, Carlsson MD, Grubb A, Hellstrom L, Persson B, Pettersson C, Spang G, Schutz A, Jarup L: Low-level cadmium exposure and osteoporosis. J Bone Miner Res 2000;15:1579-1586.

12 Jarup L, Alfven T: Low level cadmium exposure, renal and bone effects--the OSCAR study. Biometals 2004;17:505-509.

13 Katsuta O, Hiratsuka H, Matsumoto J, Iwata H, Toyota N, Tsuchitani M, Umemura T, Marumo F: Cadmiuminduced osteomalacic and osteopetrotic lesions in ovariectomized rats. Toxicol Appl Pharmacol 1994;126:58-68.

14 Regunathan A, Glesne DA, Wilson AK, Song J, Nicolae D, Flores T, Bhattacharyya MH: Microarray analysis of changes in bone cell gene expression early after cadmium gavage in mice. Toxicol Appl Pharmacol 2003;191:272-293.

15 Brzoska MM, Majewska K, Moniuszko-Jakoniuk J: Weakness in the mechanical properties of the femur of growing female rats exposed to cadmium. Arch Toxicol 2005;79:277-288.

16 Brzoska MM, Moniuszko-Jakoniuk J: Effect of low-level lifetime exposure to cadmium on calciotropic hormones in aged female rats. Arch Toxicol 2005;79:636-646.

17 Brzoska MM, Moniuszko-Jakoniuk J: Disorders in bone metabolism of female rats chronically exposed to cadmium. Toxicol Appl Pharmacol 2005;202:68-83.

18 Brzoska MM, Moniuszko-Jakoniuk J: Bone metabolism of male rats chronically exposed to cadmium. Toxicol Appl Pharmacol 2005;207:195-211.

19 Arbon KS, Christensen CM, Harvey WA, Heggland SJ: Cadmium exposure activates the ERK signaling pathway leading to altered osteoblast gene expression and apoptotic death in Saos-2 cells. Food Chem Toxicol 2012;50:198-205.

20 Kido S, Fujihara M, Nomura K, Sasaki S, Mukai R, Ohnishi R, Kaneko I, Segawa H, Tatsumi S, Izumi H, Kohno K, Miyamoto K: Molecular mechanisms of cadmium-induced fibroblast growth factor 23 upregulation in osteoblast-like cells. Toxicol Sci 2014;139:301-316.

21 Levesque M, Martineau C, Jumarie C, Moreau R: Characterization of cadmium uptake and cytotoxicity in human osteoblast-like MG-63 cells. Toxicol Appl Pharmacol 2008;231:308-317.

22 Coonse KG, Coonts AJ, Morrison EV, Heggland SJ: Cadmium induces apoptosis in the human osteoblast-like cell line Saos-2. J Toxicol Environ Health A 2007;70:575-581.

23 Matsuoka M, Igisu H: Effects of heavy metals on mitogen-activated protein kinase pathways. Environ Health Prev Med 2002;6:210-217.

24 Li Q, Chen M, Liu H, Yang L, Yang T, He G: The dual role of ERK signaling in the apoptosis of neurons. Front Biosci (Landmark Ed) 2014;19:1411-1417.

25 Sui X, Kong N, Ye L, Han W, Zhou J, Zhang Q, He C, Pan H: p38 and JNK MAPK pathways control the balance of apoptosis and autophagy in response to chemotherapeutic agents. Cancer Lett 2014;344:174-179.

26 Porras A, Zuluaga S, Black E, Valladares A, Alvarez AM, Ambrosino C, Benito M, Nebreda AR: P38 alpha mitogen-activated protein kinase sensitizes cells to apoptosis induced by different stimuli. Mol Biol Cell 2004;15:922-933.

27 Yang F, Chen H, Liu Y, Yin K, Wang Y, Li X, Wang G, Wang S, Tan X, Xu C, Lu Y, Cai B: Doxorubicin caused apoptosis of mesenchymal stem cells via p38, JNK and p53 pathway. Cell Physiol Biochem 2013;32:10721082.

28 Wang M, Li Y, Wu M, Wang W, Gong B, Wang Y: WWOX suppresses cell growth and induces cell apoptosis via inhibition of P38 nuclear translocation in cholangiocarcinoma. Cell Physiol Biochem 2014;34:1711-1722.

29 Xie M, Yi X, Wang R, Wang L, He G, Zhu M, Qi C, Liu Y, Ye Y, Tan S, Tang A: 14-thienyl methylene matrine (YYJ18), the derivative from matrine, induces apoptosis of human nasopharyngeal carcinoma cells by targeting MAPK and PI3K/Akt pathways in vitro. Cell Physiol Biochem 2014;33:1475-1483. 


\section{Cellular Physiology Cell Physiol Biochem 2015;36:642-654 \begin{tabular}{c|l}
\hline DOI: 10.1159/000430127 & (c) 2015 S. Karger AG, Basel
\end{tabular} and Biochemistry Published online: May 182015 www.karger.com/cpb}

Hu et al.: Cadmium Induced Apoptosis in MG63 Cells

30 Wada T, Penninger JM: Mitogen-activated protein kinases in apoptosis regulation. Oncogene 2004;23:28382849.

31 Liu LJ, Liu LQ Bo T, Li SJ, Zhu Z, Cui RR, Mao DA: Puerarin Suppress Apoptosis of Human Osteoblasts via ERK Signaling Pathway. Int J Endocrinol 2013;2013:786574.

32 Yao J, Qian CJ, Ye B, Zhang X, Liang Y: ERK inhibition enhances TSA-induced gastric cancer cell apoptosis via NF-kappaB-dependent and Notch-independent mechanism. Life Sci 2012;91:186-193.

33 Sun H, Hu Y, Gu Z, Owens RT, Chen YQ Edwards IJ: Omega-3 fatty acids induce apoptosis in human breast cancer cells and mouse mammary tissue through syndecan-1 inhibition of the MEK-Erk pathway. Carcinogenesis 2011;32:1518-1524.

34 Brama M, Politi L, Santini P, Migliaccio S, Scandurra R: Cadmium-induced apoptosis and necrosis in human osteoblasts: role of caspases and mitogen-activated protein kinases pathways. J Endocrinol Invest 2012;35:198-208.

35 Chang KC, Hsu CC, Liu SH, Su CC, Yen CC, Lee MJ, Chen KL, Ho TJ, Hung DZ, Wu CC, Lu TH, Su YC, Chen YW, Huang CF: Cadmium induces apoptosis in pancreatic beta-cells through a mitochondriadependent pathway: the role of oxidative stress-mediated c-Jun N-terminal kinase activation. PLoS One 2013;8:e54374.

36 Kalariya NM, Wills NK, Ramana KV, Srivastava SK, van Kuijk FJ: Cadmium-induced apoptotic death of human retinal pigment epithelial cells is mediated by MAPK pathway. Exp Eye Res 2009;89:494-502.

37 Yiran Z, Chenyang J, Jiajing W, Yan Y, Jianhong G, Jianchun B, Xuezhong L, Zongping L: Oxidative stress and mitogen-activated protein kinase pathways involved in cadmium-induced BRL 3A cell apoptosis. Oxid Med Cell Longev 2013;2013:516051.

38 Hao C, Hao W, Wei X, Xing L, Jiang J, Shang L: The role of MAPK in the biphasic dose-response phenomenon induced by cadmium and mercury in HEK293 cells. Toxicol In Vitro 2009;23:660-666.

39 Gosslau A, Rensing L: [Oxidative stress, age-dependent [correction of age-related] cell damage and antioxidative mechanisms]. Z Gerontol Geriatr 2002;35:139-150.

40 Guo R, Su Y, Liu B, Li S, Zhou S, Xu Y: Resveratrol suppresses oxidised low-density lipoprotein-induced macrophage apoptosis through inhibition of intracellular reactive oxygen species generation, LOX-1, and the p38 MAPK pathway. Cell Physiol Biochem 2014;34:603-616.

41 Chatterjee S, Kundu S, Sengupta S, Bhattacharyya A: Divergence to apoptosis from ROS induced cell cycle arrest: effect of cadmium. Mutat Res 2009;663:22-31.

42 Wang SH, Shih YL, Kuo TC, Ko WC, Shih CM: Cadmium toxicity toward autophagy through ROS-activated GSK-3beta in mesangial cells. Toxicol Sci 2009;108:124-131.

43 Zhou YJ, Zhang SP, Liu CW, Cai YQ: The protection of selenium on ROS mediated-apoptosis by mitochondria dysfunction in cadmium-induced LLC-PK(1) cells. Toxicol In Vitro 2009;23:288-294.

44 Oh SH, Lim SC: A rapid and transient ROS generation by cadmium triggers apoptosis via caspasedependent pathway in HepG2 cells and this is inhibited through $\mathrm{N}$-acetylcysteine-mediated catalase upregulation. Toxicol Appl Pharmacol 2006;212:212-223.

45 Rezzonico R, Cayatte C, Bourget-Ponzio I, Romey G, Belhacene N, Loubat A, Rocchi S, Van Obberghen E, Girault JA, Rossi B, Schmid-Antomarchi H: Focal adhesion kinase pp125FAK interacts with the large conductance calcium-activated hSlo potassium channel in human osteoblasts: potential role in mechanotransduction. J Bone Miner Res 2003;18:1863-1871.

46 Li WX, Chen SF, Chen LP, Yang GY, Li JT, Liu HZ, Zhu W: Thimerosal-induced apoptosis in mouse C2C12 myoblast cells occurs through suppression of the PI3K/Akt/survivin pathway. PLoS One 2012;7:e49064.

47 Azijli K, Yuvaraj S, van Roosmalen I, Flach K, Giovannetti E, Peters GJ, de Jong S, Kruyt FA: MAPK p38 and JNK have opposing activities on TRAIL-induced apoptosis activation in NSCLC H460 cells that involves RIP1 and caspase-8 and is mediated by Mcl-1. Apoptosis 2013;18:851-860.

48 Zhao Y, Tan Y, Dai J, Li B, Guo L, Cui J, Wang G, Shi X, Zhang X, Mellen N, Li W, Cai L: Exacerbation of diabetesinduced testicular apoptosis by zinc deficiency is most likely associated with oxidative stress, p38 MAPK activation, and p53 activation in mice. Toxicol Lett 2011;200:100-106.

49 Smith SS, Reyes JR, Arbon KS, Harvey WA, Hunt LM, Heggland SJ: Cadmium-induced decrease in RUNX2 mRNA expression and recovery by the antioxidant N-acetylcysteine (NAC) in the human osteoblast-like cell line, Saos-2. Toxicol In Vitro 2009;23:60-66. 

Cellular Physiology Cell Physiol Biochem 2015;36:642-654
\begin{tabular}{l|l} 
DOI: 10.1159/000430127 & 2015 S. Karger AG, Basel \\
and Biochemistry & Published online: May 182015
\end{tabular}

Hu et al.: Cadmium Induced Apoptosis in MG63 Cells

50 Chen S, Ren Q, Zhang J, Ye Y, Zhang Z, Xu Y, Guo M, Ji H, Xu C, Gu C, Gao W, Huang S, Chen L: N-acetyl-Lcysteine protects against cadmium-induced neuronal apoptosis by inhibiting ROS-dependent activation of Akt/mTOR pathway in mouse brain. Neuropathol Appl Neurobiol 2014;40:759-777.

51 L'Hoste S, Chargui A, Belfodil R, Duranton C, Rubera I, Mograbi B, Poujeol C, Tauc M, Poujeol P: CFTR mediates cadmium-induced apoptosis through modulation of ROS level in mouse proximal tubule cells. Free Radic Biol Med 2009;46:1017-1031.

52 Yang YH, Li B, Zheng XF, Cheng JW, Chen K, Jiang SD, Jiang LS: Oxidative damage to osteoblasts can be alleviated by early autophagy through the endoplasmic reticulum stress pathway-implications for the treatment of osteoporosis. Free Radic Biol Med 2014;10.1016/j.freeradbiomed.2014.08.028

53 Blenis J: Signal transduction via the MAP kinases: proceed at your own RSK. Proc Natl Acad Sci U S A 1993;90:5889-5892.

54 Genestra M: Oxyl radicals, redox-sensitive signalling cascades and antioxidants. Cell Signal 2007;19:18071819. 